\title{
Efforts to Increase The Activity Students through Example Non Example Models In Thematic Learning in SD N 1 Karangmalang
}

\author{
Rumanti \\ SD N 1 Karangmalang \\ rumanti2014@gmail.com
}

\section{Article History}

accepted 14/11/2020

approved $21 / 11 / 2020$

published 26/11

\begin{abstract}
The purpose of this study is an effort to increase the activeness of students with the example non example learning model in class 1 thematic learning theme 3 sub-theme 1 morning activities. This research was conducted through a cycle assessment process consisting of four stages, namely: planning, implementing, observing, and reflecting in three cycles of improvement. The conclusions obtained from this study are: (1) Thematic learning with theme 3 sub-themes 1 morning activities using the example non example model can increase the activity and learning outcomes of students. This can be seen from the activeness of students before and after the implementation of the example non example learning model in learning. In the first cycle showed active learning (55\%) and learning outcomes (61\%). In Cycle II it was able to increase learning activeness (79\%) and learning outcomes (85\%). In Cycle III was able to increase learning activeness (96\%) and learning outcomes (94\%).
\end{abstract}

Keywords: Model non example example, activeness outcomes

\begin{abstract}
Abstrak
Tujuan dari penelitian ini adalah upaya meningkatan keaktifan peserta didik dengan model pembelajaran example non example pada pembelajaran tematik kelas 1 tema 3 subtema 1 kegiatan pagi hari . Penelitian ini dilakukan melalui proses pengkajian berdaur yang terdiri dari empat tahapan, yaitu : Perencanaan, Pelaksanaan, Observasi, dan refleksi dalam tiga siklus perbaikan. Kesimpulan yang diperoleh dari penelitian ini adalah : (1)Pembelajaran tematik tema 3 subtema 1 kegiatan pagi hari menggunakan model example non example dapat meningkatkan keaktifan dan hasil belajar peserta didik. Hal ini dapat di lihat dari keaktifan peserta didik sebelum dan sesudah diterapkannya model pembelajaran example non example dalam pembelajaran. Pada siklus I menunjukan keaktifan belajar(55\%) dan hasil belajar $(61 \%)$. Pada Siklus II mampu meningkatkan keaktifan belajar(79\%)dan hasil belajar(85\%). Pada SiklusIII mampu meningkatkan keaktifan belajar (96\%) dan hasil belajar (94\%).
\end{abstract}

Kata kunci: Model example non example, keaktifan siswa

Social, Humanities, and Education Studies (SHEs): Conference Series https://jurnal.uns.ac.id/shes

p-ISSN 2620-9284

e-ISSN 2620-9292 


\section{PENDAHULUAN}

Pendidikan adalah usaha sadar dan terencana, hal ini berarti bahwa proses pendidikan di sekolah yang dilakukan antara pendidik dan peserta didik, diarahkan untuk pencapaian tujuan pendidikan. Pendidikan ialah untuk mewujudkan suasana belajar dan proses pembelajaran. Artinya, bahwa dalam pendidikan, antara proses dan hasil belajar hendaknya berjalan seimbang untuk membentuk peserta didik yang berkembang secara utuh.

Dalam suatu pembelajaran pastinya guru menginginkan peserta didik yang aktif tapi pada kenyataannya kadang siswa kurang aktif dalam pembelajaran disinilah nanti guru di harapkan untuk mengguanakan terobosan- terobosan dimana bisa menbuat peserta didik untuk aktif dalam pembelajaran. Keaktifan dapat ditingkatkan dan diperbaiki dalam keterlibatan siswa pada saat belajar. Melalui model axample non Example diharapkan bisa meningkatkan keaktifan peserta didik.

Merosotnya motivasi belajar peserta didik yang mempengaruhi kualitas pembelajaran karena kurangnya ketrampilan guru dalam pembelajaran sehingga dibutuhkan variasi model dalam pembelajaran untuk meningkatkan kualitas interaksi pembelajaran khususnya dalam meningkatkan keaktifan siswa dalam aktifitas belajar ketika pembelajaran berlangsung.

Hal ini menjadi pertimbangan pendidik dalam menentukan model pembelajaran. Model pembelajaran sebelumnya menjadi tolak ukur untuk menentukan model pembelajaran yang nantinya dapat meningkatkan keaktifan dan hasil peserta didik.

Model pembelajaran yang tepatakan berdampak pada pelaksanaan pembelajaran. Karena model pembelajaran akan mampu membawa peserta didik aktif dan termotivasi dalam mengikuti pembelajaran yang dilakukan secara daring. Dalam proses pembelajaran pendidik adalah fasilitator yang menstransfer materi yang akan disampaikan. Sehingga peserta didik harus memiliki model pembelajaran yang tepat agar materi yang disampaikan selalu diingat oleh peserta didik.

Solusi dari permasalahan diatas yaitu dengan peningkatan keaktifan belajar akan mampu meningkatkan hasil belajar peserta didik. Melalui model example non example akan mampu membawa perubahan kepada peserta didik dalam mengikuti pembelajaran

Berdasarkan latar belakang masalah diatas peneliti mengambil judul "Upaya meningkatkan keaktifan peserta didik kelas 1 melalui model example non example pada pembelajaran tematik tema 3 subtema 1 kegiatan pagi hari SD $N 1$ Karangmalang Kecamatan Bobotsari Kabupaten Purbalingga Tahun Pelajaran 2020/2021". bagaimana penerapan model Example non Example dapat meningkatkan motivasi belajar peserta didik kelas I pada pembelajaran tematik tema 3 subtema 1 kegiatan pagi hari SD NEGERI 1 KARANGMALANG tahun pelajaran 2020/2021.

\section{METODE}

Penelitian ini adalah penellitian adalah penelitian tindakan kelas (Classroom Action Research) dengan menerapkan model pembelajaran example non example. Menurut Hopkins (1993), penelitian tindakan kelas diawali dengan perencanaan tindakan (Planning), penerapan tindakan (action), mengobservasi dan mengevaluasi proses dan hasil tindakan (Observation and evaluation). Sedangkan prosedur kerja dalam penelitian tindakan kelas terdiri atas empat komponen, yakni perencanaan (planning), pelaksanaan (acting), pengamatan (observing), dan refleksi (reflecting), dan seterusnya hingga perbaikan atau peningkatan yang diharapkan tercapai (kriteria keberhasilan). Analisis penelitian ini adalah analisis deskriptif, kuantitatif kualitatif dimana dalam peneliatian ini selain penyajian hasil berupa data maupun angka peneliti juga menentukan bagaimana cara pengolahan hasil penelitian yakni dengan membuat analisisnya dengan menerapkan model pembelajara example non example. Penelitian 
ini dilaksanakan pada peserta didik kelas I SD Negeri Karangmalang Tahun Pelajaran 2020/2021 selama tiga siklus secara daring menggunakan aplikasi Zoom Meet. Siklus I dilaksanakan pada tanggal 16 November 2020. Siklus ke II dilaksanakan pada tanggal 24 November 2020. Dan Siklus 3 dilaksanakan pada tanggal 04 Desember 2020. Teknik pengumpulan data yang dilakukan dengan observasi dan tes, baik pre test maupun post test. Observasi meliputi observasi keterlaksanaan model pembelajaran example non example, sikap peserta didik dan ketrampilan. Untuk hasil belajar menggunakan tes melalui Google form.

\section{HASIL DAN PEMBAHASAN}

Penelitian tindakan kelas ini dilaksanakan dalam dua siklus yaitu siklus I materi kelas 1 tema 3 subtema 1 kegiatan pagi hari, siklus 2 materi kelas 1 tema 3 subtema 1 kegiatan pagi hari 2 setiap siklus waktu 1 hari pembelajan yaitu 105 menit. Setiap akhir siklus diadakan ulangan harian untuk mengetahui hasil belajar peserta didik. Kondisi awal pada pembelajaran tematik kelas 1 tema 3 subtema 1 di SD Negeri 1 Karangmalang pada materi kagiatan pagi hari cenderung bersifat informatif atau transfer ilmu pengetahuan dari guru ke siswa sehingga siswa kurang berminat terhadap pembelajaran akibatnya hasil belajar rata-rata yang belum mencapai KKM. Hal ini tampak pada nilai rata-rata hasil ulangan harian yang diperoleh siswa kelas 1 pada kondisi awal dengan nilai rata-rata rendah dari jumlah siswa sebanyak 33 orang dan baru 16 siswa atau 49\% saja yang telah tuntas KKM dengan nilai KKM 70.

\section{Tabel 1. Rekapitulasi Peningkatan Keaktifan Belajar Peserta Didik Dari Siklus} Awal Sampai Siklus III.

\begin{tabular}{llllll}
\hline No. & Uraian & \multicolumn{2}{l}{$\begin{array}{l}\text { Peserta didik yang belum } \\
\text { aktif }\end{array}$} & Peserta didik yang sudah aktif \\
\cline { 3 - 6 } & & Frekuensi & $\%$ & Frekuensi & $\%$ \\
\hline 1. & Studi Awal & 17 & 52 & 16 & 48 \\
\hline 2. & Siklus I & 11 & 38 & 22 & 66 \\
\hline 3. & Siklus II & 8 & 25 & 25 & 75 \\
\hline 4. & Siklus III & 3 & 10 & 30 & 90 \\
\hline
\end{tabular}

Berdasarkan penelitian tindakan kelas siklus I dan siklus II sera siklus III menunjukan peningkatan pada keaktifan belajar siswa. Pada kondisi awal siswa yang menunjukan keaktifan siswa yang pada pra siklus hanya $48 \%$ meningkat menjadi $66 \%$ pada siklus I meningkat $18 \%$ sedangkan pada siklus II menjadi $75 \%$ serta pada siklus III menjadi $90 \%$.

\section{Tabel 2. Rekapitulasi Peningkatan Hasil Belajar Peserta Didik Dari Siklus Awal} Sampai Siklus III

\begin{tabular}{llllll} 
No. & Uraian & \multicolumn{2}{l}{$\begin{array}{l}\text { Peserta didik yang } \\
\text { belum aktif }\end{array}$} & \multicolumn{2}{l}{$\begin{array}{l}\text { Peserta didik yang } \\
\text { sudah aktif }\end{array}$} \\
\cline { 3 - 6 } & Frekuensi & $\%$ & Frekuensi & $\%$ \\
\hline 1. & Studi Awal & 17 & 51 & 16 & 49 \\
\hline 2. & Siklus I & 10 & 39 & 23 & 61 \\
\hline 3. & Siklus II & 5 & 15 & 28 & 85 \\
\hline 4. & Siklus III & 2 & 6 & 31 & 94
\end{tabular}

Dari data kualitas pelaksanaan perbaikan pembelajaran dari hasil tes formatif siswa yang ditemukan dalam penelitian kelas siklus I di kelas 1 SD Negeri 1 Karangmalang dapat diketahui bahwa pelaksanaan perbaikan pembelajaran meningkat dan pembelajaran berjalan dengan baik. Dari data hasil tes evaluasi menunjukan bahwa. Ketuntasn belajar pada kondisi awal adalah $49 \%$ meningkat menjadi $61 \%$ pada 
siklus I meningkat lagi pada siklus II menjadi 85\%. Dan pada siklus III meningkat lagi menjadi 94\%. Dilihat dari uraian diatas model exsample non example dapat meningkatkan keaktifan dan prestasi belajar siswa Kelas 1 SD Negeri 1 Karangmalang. Namun pada penelitian ini masih ada dua siswa yang belum mencapai KKM.

\section{SIMPULAN}

Berdasarkan pelaksanaan hasil penelitian dan pembahasan yang diperoleh dari pra siklus sampai dengan siklus ketiga dapat disimpukan bahawa :

1. Penggunaan model pembelajaran example non example dapat meningkatkan keaktifan siswa di kelas 1 SD Negeri1 Karangmalang. Hal ini terlihat dari lembar pengamatan yang dilakukan selama penelitian. Sebelum penelitian dilakukan minat siswa masih rendah. Namun, setelah dilakukan pembelajaran dengan model example non example di kelas 1 SD Negeri 1 Karangmalang berdasarkan data-data yang diperoleh terbukti Model pembelajaran example non example dapat meningkatakan keaktifan siswa. Pembelajaran pun terlihat lebih menarik dan menyenangkan aktifitas siswa lebih dominan dari pada guru. Siswa yang awalnya malas membaca materi menjadi suka membaca materi, hal ini berdampak positif terhadap pemahaman siswa terhadap materi.

2. Model pembelajaran example non example dapat meningkatkan prestasi belajar siswa di kelas 1 SD Negeri 1 Karangmalang. Hal ini dibuktikan dari hasil penelitian menunjukan bahwa pada saat prasiklus keaktifan siswa hanya $48 \%$ kemudian pada siklus 1 tejadi peningkatan menjadi $66 \%$, siklus II meningkat lagi menjadi $75 \%$ dan terakhir pada siklus III menjadi $90 \%$ bahkan pada hasil nilai siwa pada siklus III ada siswa yang mencapai nilai 100 . Berdasarkan hasil analisis data dapat disimpulkan bahwa penggunaan model pembelajaran example non example dapat meningkatkan prestasi belajar siswa di kelas 1 SD Negeri 1 Karangmalang Kecamatan Bobotsari Kabupaten Purbalingga.

\section{DAFTAR PUSTAKA}

Shoimin, Aris. 2014. 68 Model Pembelajaran INOVATIF dalam Kurikulum 2013. Yogyakarta: AR-RUZZ MEDIA.

Suprijono, Agus. 2012. Cooperative learning Teori dan Aplikasi PAIKEM. Yogyakarta: Pustaka Pelajar.

Hosnan. 2014. Pendekatan Saintifik dan Kontekstual dalam Pembelajaran Abad 21. Bogor: Ghalia Indonesia.

Depdiknas. 2007. Panduan Pengembangan Pembelajaran IPA Terpadu. Jakarta: Puskur Balitbang Depdiknas.

Arikunto, Suharsimi. 2006. Prosedur Penelitian Suatu Pendekatan Praktik. Jakarta: PT Rineka Cipta.

Agus Suprijono. 2009. Cooperative Learning Teori \& Aplikasi Paikem. Yogyakarta: Pustaka Pelajar.

Moh. Nazir.2013. Metode Penelitian. Jakarta: Gali Indonesia. 
Rochyandi, Yadi. (2004). Model Pembelajaran Kooperatif. Surabaya: Masmedia Buana Pustaka.

Sanjaya. 2011. Penelitian Tindakan Kelas. Jakarta: Kencana Prenada Media Group.

Sugiyono, 2012. Metode Penelitian Pendidikan Kuantitatif Kualitatif dan R\&D. Bandung: Alfa Beta. 